\title{
Changing Conceptions of Writing through Situated Activity in a Geology Major
}

\author{
Enrique Paz, Southern Illinois University Carbondale
}

\begin{abstract}
This essay explores how students' misconceptions about writing might be transformed into accurate threshold concepts of writing through disciplinary writing experiences. Through an activity analysis of a geology major and students' writing in that program, I demonstrate that these students' conceptions of writing changed through their legitimate peripheral participation in geological activity. Students' learning in the major situated writing within the activity of professional geological communities, and they recognized both how writing constructs and circulates knowledge within their discipline and their need for writing to enable participation in those communities. Their example suggests that WID programs attend to conceptual change and legitimate peripheral participation as essential mechanisms for creating transformative writing experiences that enable student learning.
\end{abstract}

Scholars exploring learning and expertise, threshold concepts, and science education have dedicated much time to exploring the impact accurate conceptions and misconceptions have on student learning (Ambrose et al., 2010; Meyer \& Land, 2006b;National Research Council, 1997; Leonard et al., 2014). Their takeaway is this: throughout their education and lives, students often and easily develop misconceptions about all sorts of phenomena that can compound over time, persist throughout their education, and interfere with their learning. Without confronting those misconceptions and exploring alternative, accurate conceptions to replace them, students may have trouble deeply integrating their learning for future application or may only see narrow opportunities for application of that learning. These conclusions carry important implications for how writing pedagogy engages students' prior knowledge and experiences in courses that introduce new writing knowledge to students. This body of scholarship pushes curriculum to consider the problem of conceptual change: how can teachers of writing challenge misconceptions and encourage students to transform those beliefs into accurate threshold concepts of writing?

I argue in this essay that curricula built on situated writing experiences can meet this need. In addition to enabling students to learn effective writing practices, these experiences also enable conceptual change that encourages their learning about writing. These programs ask students to learn about and engage in activity similar to those of the professional communities they seek to join. Students use similar mediational tools on similar disciplinary objects in pursuit of similar professional outcomes and goals. In turn, their work with writing becomes more transformative, moving students through threshold conceptions to develop accurate representations of writing's use and function in professional and disciplinary practice.

Across the Disciplines

A Journal of Language, Learning and Academic Writing

wac.colostate.edu/atd

https://doi.org/10.37514/ATD-J.2022.18.3-4.07

ISSN 554-8244

Across the Disciplines is an open-access, peer-reviewed scholarly journal published on the WAC Clearinghouse and supported by Colorado State University and Georgia Southern University. Articles are published under a Creative Commons BY-NC-ND license (Attribution-NonCommercial-NoDerivs) ISSN 1554-8244. Copyright (C) 1997-2022 The WAC Clearinghouse and/or the site's authors, developers, and contributors. Some material is used with permission. 
To make this argument, I examine the context and experiences of geology students in a geology and earth science program that has vertically integrated writing instruction into its curriculum. These situated experiences of writing helped geology students transform generic conceptions of writing as expression into accurate, threshold concepts, such as that writing mediates disciplinary activity and that writing plays a role in forming professional identities (Bazerman, 2015; Estrem, 2015). Accordingly, they value writing for their future careers and believe they need to develop their writing abilities to contribute successfully to geological knowledge and communities.

The experiences of these geology majors suggested that these students negotiate conceptual change around writing to arrive at these productive outcomes for two reasons. First, coursework in geology situates writing within the activity of professional geological communities. Students, faculty, and the curriculum as a whole share a similar motive and object of activity as professional activity systems: production, promotion, and application of geological knowledge. Students learn about writing as a mediating tool in service of this motive and engage in learning to write more seriously because of this function. Second, through their legitimate peripheral participation in geological communities sponsored by the program (Lave \& Wenger, 1991), students negotiate their developing identities as geology professionals and recognize writing as a necessary practice to participate in the disciplinary community. Students see clear connections between the specific writing practice of geology and their desired professional identities in communities of geological activity as scientists and geologists. Through these experiences, students developed accurate conceptions about writing that include writing's mediating function for disciplinary activity.

Through the example of these students, I call attention to the need for curricular strategies that encourage conceptual change around writing and demonstrate how situated, disciplinary writing experiences accomplish that goal. Legitimate peripheral participation through writing enables richer understanding of both the production of knowledge in a discipline but also of writing's mediating function within those disciplinary systems. As students learn subject matter expertise through and with writing, they recognize how writing enables their own future ability to contribute as professionals in that subject. In other words, they learn what writing does, how it works in their field, and the work they can accomplish with and because of writing. These realizations come through their active learning experiences that challenge their misconceptions and transform them into accurate conceptions of writing-in this case-in the sciences.

I begin by defining the activity system which the geology department has created in its curricular and extra-curricular programs, describing the geology major's writing curricula and the experiences that students shared from that coursework. I then examine how geology students describe their changing conceptions around writing's mediational role in their discipline and the disciplinary nature of writing. Two case studies demonstrate further how these experiences in the geology major have encouraged negotiations around conceptual change and identity formation. Their examples reveal how geology students changed their conceptions about writing, developing a disciplinarily-situated relationship with writing. Finally, I describe how these reports reveal an experience of legitimate peripheral participation in geological communities. Engagement in and imaginations about these communities encourage students to build their professional identities and understand how writing enables their successful (future) participation in those communities.

Their experiences illustrate the mechanisms that provide writing-in-the-disciplines programs the potential for transformative writing experiences: conceptual change and legitimate peripheral participation. Programs that attend to their students' ability to engage in the activity of their discipline and make visible writing's mediational function in that activity will yield students who recognize the value of writing and engage learning about writing more deeply. 


\section{Considerations for Conceptual Change}

Conceptions-accurate and inaccurate-form and entrench not only over a long history of learning but also through our everyday interactions with the world and society-including school, family, media, and folklore. We "quite naturally form ideas from our everyday experience..." (Lucariello, \& Naff, 2010), which in turn inform our future interactions and learning about those experiences. While accurate conceptions enable learning, misconceptions can make learning more difficult. Gooding and Metz (2011) describe the formation of misconceptions in this way:

The learner [when they encounter new information] builds explanations, unravels problems, and files new data based on faulty reasoning. The resulting misconceptions can be compounded by linkages to other misunderstanding or inaccuracies... (p. 35)

In Science Teaching Reconsidered: A Handbook, the National Research Council (1997) identify several types of misconceptions and common examples found in science education (p. 29-31). Children might develop their own preconceived notions, for example, about how gravity and momentum work and attempt all sort of ill-advised stunts based on those beliefs. Students may learn or be taught conceptual or factual misconceptions. The National Research Council offers the example of "lightning never strikes the same place twice" as a factual misconception that is often learned when we are children and that is rarely challenged. Many such misconceptions develop when we are younger and compound as we build new knowledge alongside and on top of them. As they build, this prior knowledge can both encourage learning and interfere with it (Ambrose et al., 2010; Lucariello \& Naff, 2010; Duit \& Treagust, 2003)

In writing classrooms, teachers encounter these kinds of misconceptions all the time. Take, for example, the use of "grammar" as a catch-all word for students to describe the strengths and weaknesses of their writing. Such usage reveals a conceptual misunderstanding about effective writing: that "good" writing is simply about having grammatically, syntactically correct sentences. Another instructive example may be the belief that all strong introductions must start with a surprising quote or statistic. Students may have learned this misconception through prior writing instruction or researching writing tips online.

Regardless of when or how we develop misconceptions, they are quite stubborn and difficult to overcome. Gooding and Metz (2011) warn, "The longer a misconception remains unchallenged, the more likely it is to become entrenched" (p. 35). This deep entrenchment is all the more difficult to disrupt as many misconceptions develop specifically to explain new observations and phenomena. As Ambrose et al. (2010) describe, "In many cases, misconceptions may allow for successful explanations and predictions in a number of everyday circumstances" (p. 25). For example, the ubiquity of the "shocking quote/statistic" introduction may lead many students to believe it is always the most effective tactic. Nonetheless, because misconceptions may interfere with student learning, teachers must help students confront their misconceptions and work through conceptual change.

Changing these misconceptions is a tremendous challenge that can prove quite troublesome. "Troublesomeness" in learning has been examined at length by scholarship in threshold concepts. Threshold concepts are difficult but important ideas that deeply inform the work of a discipline or practice, but they can also be quite unintuitive or difficult to comprehend, often because these ideas may challenge misconceptions, such as when students struggle to embrace that writing can be multimodal while composing a video). In a variety of publications on threshold concepts, Meyer and Land (2006a) and other collaborators have explored the "troublesome" work of learning threshold concepts for students. In their foreword to the collection Overcoming Barriers to Student Learning: Threshold Concepts and Troublesome Knowledge, they write, 
A threshold concept represents a transformed way of understanding, or interpreting, or viewing something without which the learner cannot progress. [...] However, such transformation...may prove troublesome to certain learners for a variety of reasons, not the least of which is that such transformation entails a letting go of earlier, comfortable positions and encountering less familiar and sometimes disconcerting new territory. (Meyer and Land, 2006a, p. xv)

Much like threshold concepts, conceptual change often requires a transformation of long-held views that help us make sense of the world, and students experience that same discomfort and troublesomeness as a result.

The difficulty of conceptual change will often lead to incomplete change. For some students, "this state of 'liminality', the space of transformation, can also become a suspended state or 'stuck place" (Land et al., 2008, p. x). Stuck in the midst of this change, students' understanding and application of new knowledge may lack authenticity or deep integration, (Meyer \& Land, 2005; Perkins, 2008). Some students may avoid uncomfortable conceptual change by temporarily taking on practices, language, and beliefs for a class or semester, which they discard once they no longer need them. "Stuck" students may also "oscillate" between the competing new and old conceptions, at times operating within their prior misconceptions even after demonstrating some change in understanding (Meyer \& Land, 2006b, p. 24; Entwistle, 2008, p. 24).

Misconceptions and threshold concepts scholarship then point toward two important themes for the learning of writing and that I take up in this study. First, misconceptions abound in learning, and their pernicious effects can prevent students from engaging new knowledge appropriately. Second, changing those conceptions is quite difficult and often uncomfortable. Writing curricula then must consider how they challenge misconceptions that may interfere with learning to write and how they support students through the liminality of conceptual change.

\section{Methods}

To take up the challenge presented by misconceptions research, this study examines students' conceptions around writing and how those conceptions have formed and changed through their curricular experiences in a geology major. I aim to answer the following questions:

1. What conceptions do geology students articulate about writing, particularly as it relates to their discipline and professions?

2. How do students form these conceptions? What activities and experiences create opportunities for conceptual formation and/or enable conceptual change?

3. How do these conceptions inform how students imagine their future writing practice, activities, and professional identities?

Recruitment. This study took place at a mid-size, public, doctoral-granting university in the United States Midwest during the spring of 2017. With support and an introduction from the chair of the Geology department, several faculty invited me to visit their 300- and 400-level geology courses to recruit majors into this IRB-approved study. From these sites, I recruited 22 geology students who signed up for focus group interviews on their experiences with writing in geology. These students included 4 first-year students, 9 sophomores, 4 juniors, and 5 seniors. This recruitment yielded 6 focus group interviews. All students were invited to a round of individuals interviews, and six students-1 sophomore, 2 juniors, and 3 seniors-accepted. 
Data Collection. Students first participated in semi-structured, focus-group interviews. These interviews asked questions about participants' own definitions of writer and writing, writing experiences in coursework, possibilities for writing in their future careers, and writing's importance to their major overall. Five focus groups lasting approximately 15 minutes took place during an openlab session of a 300-level geology course and featured mixed groups of lower-level and upper-level geology students. A final focus group conversation with 2 seniors took place separately and lasted 45 minutes as the seniors spoke free of the time constraints of a class.

Six students from the focus groups agreed to speak with me more in semi-structured, individual interviews that questioned participants about their history of learning to write: what formative experiences-positive or negative-impacted their relationship with writing, what influences shaped their view of writers and their own writing, and how they negotiated writing in their major. I employed here a version of discourse-based interviews modeled after the examples of Ivanič (1998) and Odell, Goswami, and Herrington (1983), where the researcher asks participants to provide writing samples which form the basis for the interview. Ivanič's (1998) (and Odell et al's [1983]) method emphasizes exploration of rhetorical choice and genre by asking participants to compare texts and discuss choices, but my interviews emphasized students' beliefs, histories, and practices of writing as captured through these writing samples. I used this collection of samples to understand how the student used writing for their professional and personal lives and what beliefs informed that use. I asked students to provide 4 samples that each fit the following categories:

1. Writing that represented what they do when they write.

2. Writing that represented the writing they do in their major.

3. Writing that they particularly enjoyed doing or were proud of.

4. Writing that they particularly did not enjoy or found very difficult.

During our interview, I asked students to reflect on their submitted writing, describing why they chose them and where they learned to produce the sort of writing represented. Students received a $\$ 10$ gift card of their choice for their participation in individual interviews. In addition to these student interviews, a geology faculty member also participated in an interview regarding the formation of the geology program's approach to writing instruction. This same faculty member also reviewed and approved the descriptions of the program presented here.

Analysis. All student interviews were transcribed and imported into NVivo for coding and analysis. Coding began with an initial set of 3 macro-codes-"descriptions of the major," "descriptions of writing/writers", and "descriptions of self and writing"-which categorized broadly students' experiences in their major, their conceptions about writing, and their own practices and selfdefinitions. This initial coding step was followed by a second round of coding that drew from activity theory, communities of practice theory (Wenger, 1999), and identity theory (Stets \& Burke, 2000; Gee, 2000) to identify comments that described activity (e.g., objects of study, tools, etc.), learning (histories, theories), and (professional) identity negotiations (definitions of self, practices, dispositions, etc.). A final third round of coding explored more specific trends within the comments.

Limitations. I acknowledge several shortcomings of my data collection that limit its results and which may be addressed in future research. First, my research participants are markedly homogenous. While I did not ask students for any demographic information, it was clear that most participants reflected the most common demographic of this university's students: white students from fairly affluent backgrounds. Without demographic information, I cannot provide specific numerical data, but minority populations were not well represented in this study. 
Second, this study did not observe any community activity in action. All data comes from student reports of what occurs in these communities. For example, I have no data representing how these instructors actually teach writing in the classroom. Certainly, this is not to discount the richness that reflective self-reporting can offer, but I cannot make any claims in this study about these practices in situ, such as how instructors teach writing, how students discuss writing assignments with instructors during class, how students collaborate on peer-review and assignments, or how their (mis)conceptions manifest in class discussions. I also note that the reflective discussion with students about writing in their major may have encouraged or provided opportunity for students to make new connections and conceptions around their writing experiences, which they otherwise may not have recognized.

Lastly, I also recognize the limitations of looking for evidence of conceptual change through this method of reflective interviews rather than through longitudinal approaches. My method provides no data for triangulating students' self-reporting of change as evidenced in writing or beliefs across time. My hope is to offer here a starting point upon which future longitudinal studies might build.

\section{Studying Curricular Work in Geology through Activity Theory}

To better understand the work of the geology program, I turn to activity theory as a tool for analysis. Situated learning theories, particularly activity theory, have demonstrated how students' successes and struggles with writing may result from how those experiences are or are not situated contextually within a shared activity system (Bazerman \& Russell, 2003; Paré \& Dias, 2000; Russell, 1995). These arguments have continued to inform scholarship on writing in the disciplines, writing across the curriculum, professional writing, and transfer (Spinuzzi, 1996; Wardle, 2004; Carter, 2007; Dias et al., 2013; Baird \& Dilger, 2017). Cultural-historical activity theory provides a robust heuristic for unpacking the geology curriculum and students' experiences within it. Building from the work of Vygotsky, theorists Leont'ev (1978) and Engeström (1987) have developed activity theory as an analytical tool for understanding human activity, learning, change, and development through mediational relationships. It examines social activity as practice that is always situated within historical and cultural contexts. By mapping these relations and the motives underlying these practices, activity theory helps make sense of how people participate meaningfully in their human activity and how that participation is organized (Roth \& Lee, 2007).

Activity theory shares much affinity with the misconceptions scholarship described above and with Etienne Wenger's (1999) communities of practice theory and Lave and Wenger's (1991) theory of legitimate peripheral participation. In Lave and Wenger's Situated Learning and Wenger's Communities of Practice, these scholars explore people integrating into new professions and organizations and how they develop professional expertise and social practices within those contexts. While activity theory helps recognize how social systems are organized, Lave and Wenger's work provides a lens for examining how newcomers integrate into these systems and learn to participate meaningfully in them. They both call attention to the context of activity, to the people, goals, resources, norms, and relationships within these systems. Activity theory maps relationships between these features of a community, whereas legitimate peripheral participation attends to how one learns these features and becomes adept with them. Most recently, writing scholarship that employs activity theory or legitimate peripheral participation have met more explicitly in conversations about threshold concepts in writing studies (Adler-Kassner \& Wardle, 2015; Anson \& Moore, 2017). This scholarship encourages researchers to consider how threshold concepts of writing inform students' experiences in writing programs and how their ways of knowing and doing with writing may be transformed by accurate conceptions. I now take up that call by attending to students' misconceptions and their transformations. 
While students in writing-about-writing classes or writing majors may receive direct exposure to composition theory that can encourage accurate conceptions, it is unclear how other disciplinary programs can teach writing in ways that move students through misconceptions to threshold concepts of writing. Several studies acknowledge how WID programs have helped students develop genre knowledge and understand disciplinary content and norms in professional writing, STEM and other fields (Wilcox, 2017; Goldschmidt, 2014; Leydens \& Santi, 2006). Their research reveals how practice can be productively transformed through writing experiences situated within disciplinary motives, goals, and exigencies. Other works by Downs and Wardle (2007, Thaiss and Zawacki (2006), and Poe et al. (2010) offers some insight into how beliefs about writing may also change through learning about writing in disciplinary context. In this essay, I contribute to this conversation by exploring students' conceptual transformation through curricular experiences using activity theory.

The geology program has engaged students in an activity system that mirrors the activity and work of professional geologist and geology (Figure 1). Students learn about and work with the same kinds of tools, rules, objects of study, and motives as geological communities beyond school while learning. Within this context, students encounter writing not as a discrete object of curricular study but rather as a tool to act upon the object of study (Dias et al., 2013). Their writing functions to further the motives of this professional community, and students learn about writing as situated within this activity. In this section, I use activity theory to describe the writing instruction in the geology program.

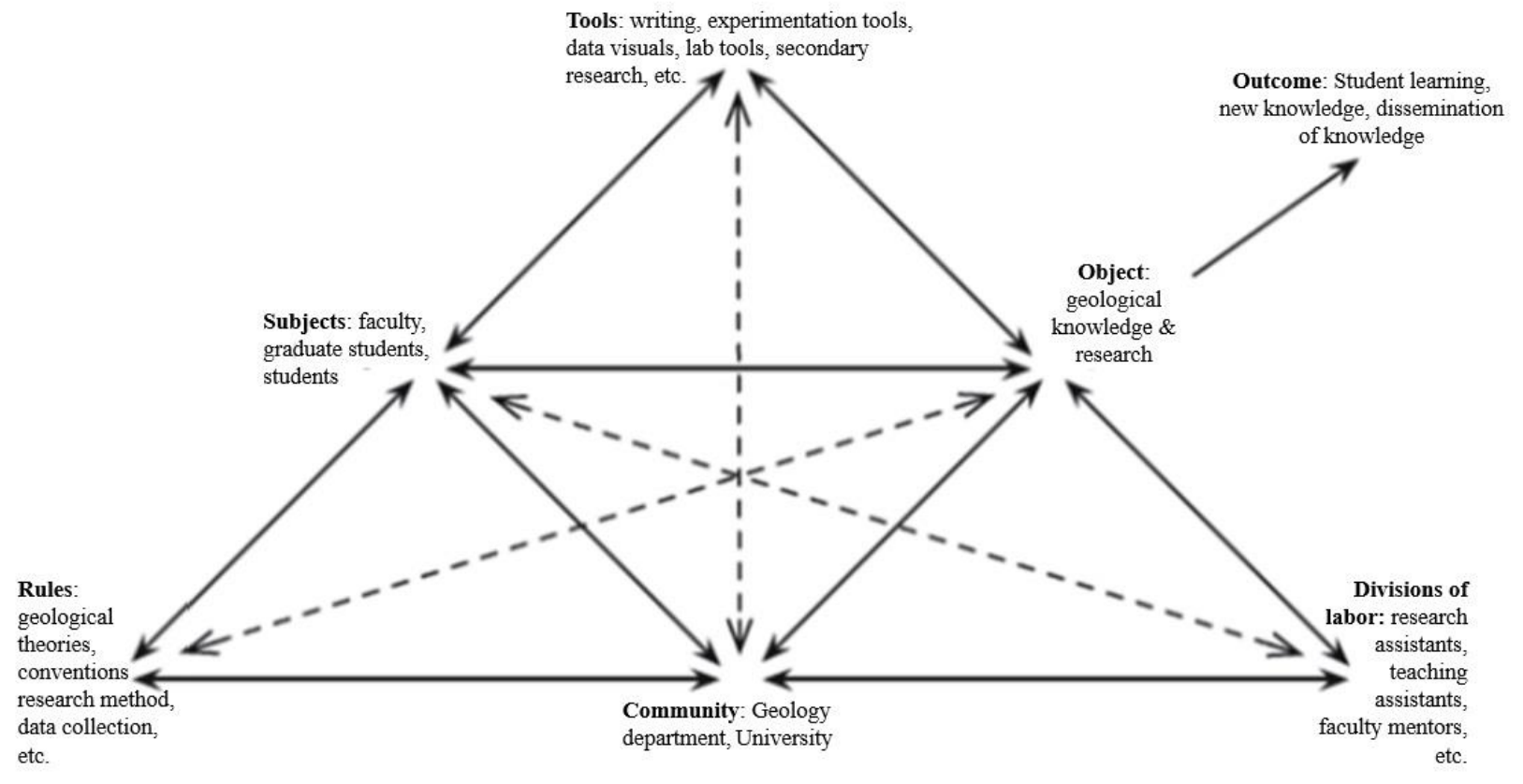

Figure 1: The activity system of the Geology major.

This university's department of Geology and Environmental Earth Sciences houses three programs whose curricula all engage students in the pursuit, exploration, and application of geological knowledge. As described on their university webpage, department programs "prepare students for further graduate work in the geosciences, as well as careers in the environmental industry, petroleum, mining, government, and education," and many of the students I spoke with articulated career goals that aligned with these descriptions (Miami University, n.d.). This department and its curricula prepare and orient their students for diverse careers and worksites-activity systemswhere they might deploy geological knowledge to participate in a variety of activities (social, environmental, academic, and professional). 
With these trajectories in mind, students engage writing constantly throughout the geology programs. This instruction does not take place in one independent writing course: there is no single "Writing in Geology" course that makes writing the object of study. Instead, they take content courses that give attention to writing instruction as a mediational means which students use to produce a desired outcome: circulation of their new knowledge via reports and publications. During an interview, the Geology faculty member serving as assessment coordinator described the curriculum as a:

scaffolded model...where students would see writing assignments with specific writing instruction through multiple courses in our major, envisioning a sort of intro, intermediate, and advanced level.

The writing-intensive courses which students must take at the 200-level (introductory) and at the 300-level (intermediate) to meet the university's Advanced Writing requirement are GLG204: Survival on an Evolving Planet, GLG211:Chemistry of Earth Systems, GLG301: Sedimentology and Stratigraphy, and GLG357: Petrology. All these courses, as their titles suggest, emphasize disciplinary knowledge but also include a significant writing component. In these and other courses, students report receiving specific instruction on genres for geological writing, formal and informal feedback on their writing, and lectures on writing in geology in these courses, as well as engaging in revision, peer review, and collaborative writing. The faculty interviewee drew attention to instruction on writing for two distinct audiences: writing for public or non-expert audiences and writing for professional and disciplinary peers. Through each "level" (introductory, intermediate, and advanced) of the curriculum and writing instruction, students encounter increasingly complex and professionalized genres for each audience. For example, in a 200-level class, students might write lab reports as a disciplinary genre and a research summary article in the style of popular magazines for public audiences. By the 400-level, they may write research reports in the style of academic publications and in-depth research summary articles for companies and organizations. The faculty interviewee described this structure as "slowly moving them closer to the professional writing in those genres," or as Wenger (1999) may describe it, moving from the periphery to the center. This writing scaffold reaches its most advanced level in the senior capstone courses where students complete significant research projects written in these professional genres of geology.

In these courses, students encounter writing within the curriculum as a tool with which to act upon the object of study: geology. As Dias et al. (2013) called for in Worlds Apart, this structure situates writing "operationally" as a rhetorical tool within the shared repertoire geologists might use to mediate the activity of their discipline and act upon the geological object of study. Senior Helen described her experience with writing in geology, stating, "In every single class it's just kind of an expectation. It's not like, 'Oh, you have to fulfill this writing requirement.' It's just the nature of our courses." Students learn to research and report on sedimentology, for example, and learn how writing helps them do that. They learn to write as they pursue their object of study-geology science and research-and use writing to participate in that study and produce outcomes that respond to the system's motives of advancing and disseminating geological knowledge.

Students develop their conceptions and ability in writing as they learn about writing's mediating function for geology. The geology curriculum exposes students to much geological writing and discussion about that writing and its function. Assignments ask students to read, summarize, and discuss geology writing frequently. They learn about research and writing as entwined practices with multiple audiences, professional and public. They write in many informal and formal genres used in professional geological practice, including grant proposals, environmental assessments, research articles, recommendation reports, research abstracts, lab reports, research reports, research field notes, conference posters and presentations, and proposals. Students demonstrated comfort with the 
forms, features, and expectations of these various genres as a result of this work. Participants often casually rattled off traditional outlines for their written genres when talking about such assignments. For example, junior Edith described a lab report she included in her portfolio, stating: "This one is for a hydrogeology class, and I think this pretty standard geology stuff where you have goals and objectives, and then your methods, results, discussion, and further research." Students saw these conventions and rules in the reading they did in class, which often served as models for writing assignments and tools for instructors to teach writing. The breadth of genre promotes a rhetorical flexibility, providing many examples of potential audiences, purposes, motives, and methods for responding to exigencies geology professional may answer through writing (Poe et al., 2010). This writing instruction ultimately allows students to explore the depth and flexibility of this mediational tool and the many forms it can take to respond to geological projects and motives. ${ }^{1}$

In both advanced writing courses and other geology courses, students encountered writing as mediational tool consistently. Senior Tyler noted, "In every class I can remember, teachers have always been reviewing the basics of certain styles of writing, specifically abstract writing and scientific articles and stuff like that, the way they're structured. I think teachers are always willing to go over that or just make it part of the lesson." Junior Harper reported: "I think writing is a big part of the major. I feel like it's close to $50 \%$ or more of the time is dedicated to writing in some way." Whatever the percentage, that time was filled with rich learning experiences around writing that included the following:

- using models to learn different genres of geological writing,

- receiving feedback at multiple stages of writing,

- writing both formal and informal genres to explore course content,

- completing scaffolded assignments that culminated in larger projects,

- receiving lectures on effective writing and science genres,

- writing collaboratively on small and large writing exercises, and

- $\quad$ working from specific rubrics teachers used for assessment and feedback.

Students have these experiences in many geology courses and come to see writing's application, form, and function for their professional pursuits through this careful instruction. Taught in this way, students not only learn about writing as a mediational tool but also learn other important threshold conceptions of writing, such as that writing is a process and all writers need feedback (Adler-Kassner \& Wardle, 2015).

Of course, writing is just one of the tools students learn to use as they perform geological activity. Throughout the curricular experience in geology, this program also teaches a deep shared repertoire of tools which mediate geological research. Students consistently cited methods of data analysis, visualizations of data, data collection methods, geological concepts, experimentation and research, labs, and scientific tools for analysis and collection. These tools are the same kinds of mediational means professional geologists deploy in their work and which eventually find expression and mediation in writing. Students become deeply familiar with this entire repertoire as they move deeper into the major.

Beyond the classroom, students also had many opportunities to participate in the community of this activity system and to mutually engage with its members, geology instructors and their fellow geology majors. Outside of the structured classroom environment, students and faculty work together in on-campus and off-campus research sites to perform research, including summer research projects and research "camps." Students are often found in labs independently performing 
research projects, where they work individually or in student teams. While some of this research is independently driven, many students also work with faculty on research projects. Additionally, the geology program hosts Friday seminars with featured speakers and presentations on geological topics. Students regularly attend them and seminar content is integrated into many courses. Students even commonly attend conferences and other disciplinary events. These locales are other sites where students and faculty continue in their joint enterprise and shared motive of pursuing new geological knowledge outside the classroom.

As a result of these experiences, students are able to see connections between their school activity and their future professional activity. All 22 geology participants recognized that writing would be essential to their professional careers. Junior Edith said, "If you want to be a professional in geology, it's an expectation that you'll be able to effectively communicate your research or whatever it is you're doing in writing. That's why the department puts such an emphasis on writing, so that you can be a professional." Junior Emma echoed these sentiments: "You might not necessarily [need writing] to be a good geology major, but if you want to work in the field you have to." These students not only recognize writing as valuable but situate writing's function within the objects and activity of geology professionals. In fact, as Emma's comment above suggests, students saw that these writing skills become most valuable when one joins the professional community. Emma doesn't limit writing's usefulness to academic success or grades, but instead she views writing rhetorically as a tool in the pursuit of the object: geological knowledge.

In these ways, the activity of the geology majors and their writing instruction overlaps with the activity systems of professional geological communities students might one day join. Students learn about, practice, and write in genres used by geology professionals. They pursue geological knowledge as the object of study and use writing as a tool in service of that pursuit. They draw from the same scientific theories, concepts, practices, research methods, and rules as professionals. And they engage their community in similar ways as professionals together and individually in labs, at conferences, and at professional and disciplinary event and seminars. This activity-based writing instruction that overlaps in productive ways with professional geological activity has affected student conceptions about writing in ways that encourage their learning and enable their professional development.

\section{Geology Students' Conceptions about Writing}

Students in this geology major have begun to develop discipline-specific conceptions about writing. They have developed these conceptions because of writing instruction that was situated within their majors and connected to the motives of their future professions in geology. They demonstrate in their definitions their understanding that writing (and being a writer) is a discipline-specific activity that defies general and generic definitions. And they associate writing as a practice that mediates the activity of science and that is required for identities as scientists and geologists (Poe et al., 2010). These generative conceptions have resulted from the situated instruction of writing in geology that shares its structure with professional activity systems in geology.

Below I examine two major conceptual themes that emerged in my conversations with geology students. First, students recognized that writing mediates the activity of (professional) communities. Because they have learned this threshold concept, students recognized the value of the writing instruction they received and made immediate connections to their future professional lives. Second, and related, students understood writing as a flexible, contextual practice that varies between disciplines and that can be used to write one's self into the discipline. Because they have developed this conception, they rejected generic understandings of writing and writers and sought to develop their writing ability as a necessary tool for their professional identities as geologists. 


\section{Student Conception: Writing is a Mediating Tool in Geology}

Geology students have learned that writing mediates the activity of their discipline. As Russell (2015) writes in Naming What We Know, writing mediates activity, and he notes that this particular threshold concept "is troublesome because it goes against the usual concepts of writing as 'just' transcribing thought or speech" (p. 27-28). In spite of this troublesomeness, students in this study demonstrate some success in working through this trouble because they have been able to see the way writing mediates the activity, motives, and goals of their future geological communities. In other words, the writing they do in their major matches the writing professional geologists do, and students are motivated to engage their learning to write more deeply because they make these connections.

Some geology students recognized that writing recorded and thereby helped substantiate the work of their discipline. Sophomore Jake, for example, stated, "And specifically in this department, the only difference between science and doing something stupid is that you wrote it down." This same student described the writing he did in geology more seriously as "writing with a purpose," which encouraged him unlike previous writing experiences:

Yeah. I really appreciate doing this writing. All throughout school, like middle school, high school, I hated writing. Hated it. I was a good writer, just hated doing it. There was just no point. Who's going to care about this ninth grader's book report on Romeo and Juliet or whatever? But here I know it's, at least... it's going to help me later in my field, as I go on and have to do writing, somebody else is going to be reading it. It's going to affect my future.

Jake, as Ambrose et al. (2010) and Lee Ann Carroll (2002) have suggested, found motivation for learning to write as he recognized its real-world purpose. In Writing in the Real World, Beaufort (1999) too demonstrated how several professionals grew as writers when their writing attended to real needs and purpose in their workplace, rather than the ungrounded or artificial audiences and tasks of many writing assignments (p. 191-2). Like Beaufort's participants, Jake found his writing purposeful and demonstrated willingness to engage in learning to write in geology accordingly.

Students found that purpose for writing as it connected them to other geologists. They were excited that others might read their work to learn from and build upon it. As Russell (2015) argues, the work of writing as mediational tool is "to form a connecting link between people to coordinate their activity" (p. 27). Students recognized this connective function when they stated that writing in geology was all about communicating the results of your research. Junior Edith noted that writing was specifically for the purpose of "translating research into something you can share." Senior Tyler believed that effective writing in geology "is being able to communicate [your research] effectively to whatever crowd you have, whether it's scientists or someone who doesn't know much about it." Students write for several such (imagined) audiences in their assignments: companies seeking reports about land (for oil, for example), government officials making environmental policies, casual readers of popular science journals, and organizations offering grants and contracts. The portfolios of writing that individual interviewees submitted featured several examples of this kind of real-world writing.

As these genre examples might suggest, students recognized that geological activity was not limited only to academics. They noted several different kinds of professional trajectories that involve differing forms of geological activity but still make use of the mediational tool of writing they had learned. Harper noted that the major emphasizes non-expert audience in particular: "[Professors] really want to hone your writing and make sure that you can make sense of things and relate it to non-scientists. That's a very significant part of the major." Senior Shannon, who wanted to work as a 
museum curator, argued that the non-expert audiences were increasingly becoming the most important audience. She learned through her experiences that appealing to this audience would require a different approach: "It is still important to state why the public should care. Because nowadays they don't really care unless it applies to their life. It's probably always been the case, but we're realizing that now." Indeed, I heard a similar claim from an instructor who invited me into his course to recruit participants. As we waited for students to file in and find their seats before class, he passionately told me about how he prepares students to write for public audiences by reading and dissecting examples of popular science articles. This kind of instruction continues throughout the major, which encourages conceptual change by learning from real models, as the National Research Council (1997) has argued (p. 31).

These students have felt their work served ends beyond the classroom and imagined these kinds of writing in their future activity, unbound from the pseudotransactionality that characterizes many other writing experiences in college (Spinuzzi, 1996). Petraglia (1995) described pseudotransactionality as writing "solely intended to meet teacher expectations rather than engage in a transference of information for the purposes of informing the uninformed or demonstrating mastery over content" (p. 21). For participants in this study, the ability to recognize potential for this writing in their future professional activity gave value to their experience. It has allowed students to recognize what writing does in professions and communities: writing mediates activity. Geology students have seen how writing helps record, substantiate, communicate, and argue for their research and other professional activity. Experiences learning to write in and for geology encouraged conceptual change around this threshold concept and to value writing for their future as geologists.

\section{Student Conception: "Writing" is Specific to each Discipline and Profession}

When describing their definitions and beliefs of what "writers" are and do, geology students defined writer contextually, as a way of doing that is always situated within a discipline. They recognized that disciplines "shape - and are reshaped by - the writing that members of those disciplines do" (Lerner, 2015, p. 40), and therefore the practice of writing and being a writer differs in each context. For geology students, learning writing as part of the disciplinary practice of doing research and sharing that research determined a key distinction of their kind of writing.

Newer geology students' descriptions of "writer" emphasized a more generic idea of writing as a generic form for communication, but advanced students offered more specific, situated nuance to their descriptions. When directly asked their definition of writer, 11 geology students, like sophomores Jake and Jill, made generic statements claiming that writers use writing to communicate their ideas and express their thoughts. Poe et al. (2010) also found that newer science students tended to focus on the transmission of knowledge as a beginning step in their learning about science writing (p. 48). Advanced students, however, added complexity to these definitions by describing practices of research and multiple audiences. Senior Shannon described writers as those who "present research in a clear and concise way that a general populace can understand." Junior Edith noted that scientific writers "try to illustrate their research findings to a broader audience so they can share their findings with everyone." These definitions add specificity about what writers communicate as well as to whom.

Many geology students spoke of writers through disciplinary conceptions. Like Edith's definition in the comment above that named specifically the scientific writer, seven students specified in their definitions that they were speaking about geology or science writers as opposed to other kinds of writers. In fact, senior Helen and junior Victoria both responded to my question, "Do you consider yourself a writer?" by rebuffing the unspecified discipline in the question. They instead asserted the contextual nature of "writer," revealing contextual conceptions of writing. Victoria specified, "It 
depends on the context. I wouldn't say I write books because that's all fluff, but I do think that scientifically, I am a writer." Some participants contrasted the science writer against a generic conception of an "English" writer or major, saying that the latter focused on writing about stories or literature while science writers work with data. Even Rachel, who was finishing her first year as a geology major at the time of our focus group, argued, "I think [communicator] is the best definition of writer you can get, especially from a scientific standpoint. Because writing is different if you're thinking about science." They learned these possibilities through the classroom experiences related to their major. Edith and Shannon cited homework and assignments they had done recently to show how their curricular experiences demonstrated to them what it means to be a writer. Sophomores Jake and Jill saw what they could do with writing in the scientific books and articles they have read in the major. These experiences have helped geology students develop contextual conceptions of writing in their discipline.

Based on these experiences, geology students described primary research as part of the process of writing in geology, again illustrating their understanding of how writing served disciplinary activity and motives. Sophomore Jill, for example, became open to views of herself as a writer when she realized research was part of that activity for geology: "I got into college and [writing in the major] was like, 'Oh, you actually have to do your own experimentation or you actually have to go out and do your own research, interview people and stuff like that?' Then that's when I figured myself more of a writer, I guess." These research-based writing experiences stood in contrast to their previous experiences, as Helen attested in this comment:

Well, at my high school, a lot of the focus was on literature writing and English, that's the majority of our writing component. And I think my high school did a good job at preparing me or teaching me how to write well. But once I declared a Geology major for college, then all of my writing shifted to being academic - I mean, research-basedwhere we'd find scientific articles and then talk about those. They're all very different from one another.

Helen again located the difference in writing to the disciplinary practice of research in geology, apart from the literary tradition of her earlier English classes. Senior Tyler likewise noted that the research practice of geology writing was where he found space to say he was a writer: "The research writer has always been, I've always been that kind of writer, I think."

This specific construction of writing as geological practice encouraged students to take their learning to write seriously. Students recognized that writing is necessary to fully and professionally participate in professional communities and their geological activities. First-year student Chelsea, for example, claimed she was working harder to be a strong writer, noting, "I know I'm going to have to do it, so I need to learn how to do it." Chelsea's words echoed among her peers who also recognized the need to develop a practice of writing for their geological careers. Sophomore Erik and senior Mitchell shared similar beliefs about their relationship to writing. Neither student wanted to claim they were "writers," but both felt writing was necessary for their future success. They shared this exchange in a focus group interview:

Erik: I think if I was meeting someone and they were like, "What do you do?" I wouldn't say I'm a writer. I'm not going to call myself a writer, but I think everyone has to write.

Mitchell: I'm in the same boat. Writing is a huge part of what I do professionally, but I'm an analyst. I'm not a writer. 
Both of these students prefer to identify with other professional titles. Erik identified as a geologist, and Mitchell as an analyst (a title he took from the career and practices he had before returning to college for a geology degree). But both saw writing as a necessary part of their professional practice and identities. In fact, all 22 geology students expressed a positive valuation of writing, noting its necessity for their career goals.

Geology students have begun to recognize, as Patricia Bizzell (1982) described, that "writing is already always writing for some purpose that can only be understood in its community context" ( $p$. 398). They have developed contextual, disciplinary definitions of writer and the purpose for writing. As they passed through this threshold concept of writing (Lerner, 2015), advanced students even rejected my generic question "What is a writer?" They instead insisted on situating "writer" within a discipline, as that was the best way for them to imagine a practice of writing for themselves and their community.

Geology students' conceptual change results from writing instruction that itself is situated within disciplinary activity. Students learn to write in the genres that professional geologists employ and use those genres to respond to questions and objects of geological activity in a variety of professional contexts. Instructors expose students to many models of writing in geology that demonstrate how professional writing shapes the discipline and enact its motives. Rather than generic images of writers as authors or geniuses (Ball \& Loewe, 2017), geology students suggest there is a "geology" writer who is a professional scientist who uses research and experimentation to produce writing which communicates with multiple audiences about their research findings, without idealizing the emotions needed for meaningful writing. With this kind of writing practice in mind, students value the writing instruction they receive and engage in deeper, transformative learning.

In addition to these two conceptions articulated across many of my geology participants, many students demonstrated individual change toward generative conceptions around writing that developed because of their learning to write within a geological activity system (Poe et al., 2010; Freedman and Adam, 1996). To learn more about this conceptual change and how it has occurred, I now turn to the cases of two specific students, Helen and Harper. Their cases illustrate the rich and nuanced way geology students may understand writing. Looking more closely at these experiences of individual students reveals more ways that the writing instruction in geology is helping students develop generative conceptions around writing.

\section{Case Studies: Helen and Harper}

The situated, disciplinary writing instruction that students receive in the geology majors can also encourage conceptual change around the process of writing and learning to write, informed by the function, purpose, and mediational use of writing for disciplines discussed above. The two students I discuss below, senior Helen and junior Harper, both recognized a distinct transition into a new kind of writing when they entered the geology major and demonstrate generative conceptions about writing as they describe their learning. Their examples illustrate in greater detail the results of conceptual change around writing. Helen used disciplinary conceptions of writing to describe her own relationship with writing and explain its value for her life, while Harper saw scientific writing as the latest step in a long process of learning to write begun in her childhood. Their experiences learning to write in geology have demonstrated to them that learning to write is always an ongoing process, that revision and intentional writing process are necessary for effective writing, and especially that writing helps develop their professional identities. Both students emphasized that writing would be necessary for their future participation in professional geological communities and took writing in their major seriously to prepare for that participation. 


\section{Helen: Conceptual Change through Disciplinarity}

Helen demonstrates several productive understandings of writing based on the disciplinary conceptions of writing she has learned in her geology major. In her interviews, she demonstrated her understanding that:

- Writing is a contextual practice that is always socially situated (Russell, 1995; Roozen, 2015).

- Writing is essential to the professional work of geology and mediates its disciplinary activity (Poe et al., 2010; Bazerman, 1997)

- Writing performs disciplinarity and develops professional and disciplinary identity (Poe et al., 2010; Estrem, 2015)

- Learning to write is an ongoing process that is never complete (Rose, 2015; Yancey, 2015).

She has adopted these concepts specifically because of the writing education she received within her discipline. The geology department, as Helen and other students described, engaged generative pedagogical strategies that reflect composition's best practices for writing instruction and strategies for promoting conceptual change. In Helen's case, the constant practice, feedback, and authentic connections to professional practice helped her adopt this new knowledge and integrate it deeply into her practice. She was motivated to do this because she knew writing was necessary to participate effectively in the activity of geology professionals.

From the outset of my conversations with her, Helen expressed uncertainty about any generic, acontextual ways of defining writers. The first question of every focus group interview asked students to define "writer," but Helen immediately moved toward specific, contextual understandings of writers and their practices:

I don't know. I guess you could come at it in so many different directions, though. There's literature writing, but then there's also research writing. And the majority of what we're doing is science writing. It's very wide. It depends on who you are talking to.

Much of my conversations with Helen returned to this point, that writing differed across disciplines and contexts, and, by extension, so did learning to write.

The distinction she emphasized between contexts for writing demonstrates her understanding that writing is not a monolithic, static practice but rather differs according to activity and audiences. While she wrote poetry and other personal, creative works in elementary and high school, she emphasized that she has left "that kind of writing" behind, and instead she moved on to science writing:

A lot of what I do now is scientific writing. So it's objective. It's comparing different datasets, or comparing results from an experiment that we ran. But then, there's also more literature-type writers, where you're now analyzing literature, different prose, and stuff like that. Yeah, I mean, there's all kinds of different intended audiences for writing.

Her comment recognized specifically that her practice of writing builds from experimentation and research, which she differentiated from practices that "literature-type" writers use to build their texts and which she practiced in high school. It also revealed a deeper rhetorical knowledge of writing, citing disciplinarity and audience. She now believed, however, that her writing practice has undergone significant change in its style. "If I had to go back and write an English paper now, I don't think I would do so well, because I haven't used those skills in so long," she explained. Again, she 
suggested a differentiation in skills between "English" and her science writing. To invoke Russell (1995), she acknowledged that her basketball has gotten rusty while she's been focusing on her soccer.

In geologic or scientific writing, Helen felt quite confident and comfortable about her writing: "I'm not a professional writer, or an English writer or a literature writer, but I think I am a writer in the sense that I possess the skills to write effectively in my chosen area [of geology]." Her ability and abundant experience with scientific writing through the major gave her confidence to claim writing as part of her professional identity. This confidence resulted from consistent writing practice and feedback she received from instructors throughout geology course work:

But I think my ability to write in our major has definitely improved over the years, because of the sheer volume. But it is definitely something you have to work at, no matter what level you come in at. You just might have to work more if you don't have generally a strong foundation.

Because the major used writing to explore course concepts, assessed understanding through writing, and delivered explicit instruction about writing in class and through feedback, Helen perceived writing as a constant in the major and attributed her writing success to this continual practice, reflecting such threshold concepts as "All writers have more to learn" (Rose, 2015, p. 59) and "Learning to write requires different kinds of practice" (Yancey, 2015, p. 64).

Although Helen's conceptions of writing and writers were often complex and situated within her disciplinary learning, she still showed evidence of negotiating the liminal space of this complex conceptual change. As Land and Meyer (2006) have noted, even though students may demonstrate significant change in thinking, misconceptions and prior frameworks are persistent. They still exert influence and surface at times when students continue to work through the difficulty of conceptual change (p. 24). So, although she claimed to always be writing in geology, Helen also made a contrary claim during our interview: she claimed not to be writing very often at all. When I asked if she enjoyed writing, she replied, "It's just okay. I don't do it much anymore, but back when I was trying to write poetry, and stuff like that, it was only when I was in the mood." Although we had been speaking entirely about geology, her focus had now shifted to poetry again. When asked about her emotional connection to writing-whether she liked or enjoyed writing-her answer appeared to default to the last place where she wrote emotionally: the poetry which she had since left behind. Helen described her scientific writing as "objective" and "factual." Practices of writing that geology students discussed had no concern for their emotional relationship toward writing. Similarly, Helen's response to my explicit question about liking writing took her away from our conversation about "factual, objective" geology writing and toward the "emotional, expressive" writing she did with poetry. She had long since abandoned this kind of writing that cared about emotion and so claimed she "didn't do writing much anymore." This push-and-pull reflected her own continuing negotiations between conceptions of writing. Helen continues to work through the liminality of conceptual change as she oscillates between her high school "English" framework for writing and her new practices in science writing, or in her words, between emotional writing and objective writing

That is not to say that Helen expressed no emotion about her geology writing. She expressed pride and joy about a capstone paper she included in her portfolio. She regularly mentioned that certain projects "sucked" and that she did not enjoy writing lab reports especially. But she dismissed those feelings as unimportant for the writing she was doing as part of her major and career: "We might grumble about lab write-ups or term papers, but we're just grumbling because it's work. It's not like we're grumbling because we think it's useless." Helen claimed she never gave much thought to liking or not liking writing because "it just was," regardless of how she felt. Her comments might reflect 
many a professional, who know the necessity of their writing even in spite of its challenges and stresses. Helen recognized writing's value for her professional activity and disregarded her feelings, both because scientific writing is "factual" but also because she understood its value to the discipline's motives, regardless of how she felt about it.

The oscillation between disciplinary and conceptual frameworks for writing highlighted in Helen's comments about poetry and literary writing versus her geological writing carried into her portfolio. In addition to three different kinds of scientific reports, Helen also submitted in her portfolio an essay from an English honors course, "Literature in the Environment." She used the essay as writing that she thought represented her "as a writer." She described her thinking in the extended exchange below, which is quite telling of the kinds of oscillations Helen may be experiencing:

Helen: This was the one that was more, I guess, reflecting who I think I am as a writer, I guess... Because it takes me back to how I used to write in high school and I just, I did feel proud of myself for being a decent writer at the end of high school. And this was the last time I wrote like this.

Enrique: Do you wish you were doing more of this kind of writing still?

Helen: I don't know. I think my voice can come through better in writing like this than in scientific writing, because I'm just writing to write. It's lighter; I think personality comes through stronger in my own writing. But with scientific writing, it's so cut and dry and, "These are the facts, these are my interpretation of them." But there's not too much room for what's happening in the system or why it's happening. And I like that type of writing because it is very factual and it's very cool because these experiments are cool and, "How do we know all these things? We've done experiments and they are really fascinating." But I did enjoy English in high school. I've always liked literature. I used to read a ridiculous amount. I read less so now because of college, but I do enjoy literature in general.

Through her portfolio choices and her reflection, Helen is still working through her former "English" and current science writing practices-what writing offered her middle and high school self and what writing offers to her current ambitions. When asked to deliver a writing sample that represented herself as a "writer," she turned back to a piece that represented a more traditional, internalized conception of "writer," one rooted in literature, passion, and self-motivation: the kind of writing she used to do but has since "left behind." But when asked about her writing today, she uses disciplinary knowledge to identify writing practices she can claim and others she cannot. While thinking between these two, her description of science writing becomes reductive ("It's cut and dry"; "no room for what's happening or why") but again demonstrates the oscillation between prior and new frameworks that would have influenced this description.

Nonetheless, based on her disciplinary experiences in geology writing, Helen recognizes writing's value to and mediating function for her professional activity. When asked to clarify why the geology major includes so much writing and writing instruction, Helen argued, "Because we have to in our careers. No matter what we do [in this field]...this is a necessary skill that, if we don't come in with, we're not going to get hired, or we're not going to do well from the beginning." While her current writing life may differ greatly from her prior writing practices, Helen works to negotiate between her former and current writing practices into her professional activity that needs writing to succeed. Through those continuing negotiations, she also works to makes sense of her whole history with writing, explaining the shifting trajectory of her writing practice and her sense of writing self in the 
process. Writing may not "express her personality" anymore but instead has become a professional practice, negotiated and sharpened through her learning to write in the major.

\section{Harper: Conceptual Change through Engagement and Imagination}

Like Helen, junior Harper has developed specific conceptions about writing that help to explain her own relationships and histories with writing and establish writing as part of her desired professional identities. She developed these conceptions because of the geology writing curriculum that situates writing explicitly as a tool for geological activity and allows students to explore, revise, and adapt their conceptions around writing through connections to professional communities of geology. Harper conceptualizes her transition into science writing as an act of integration-acquiring many different writing practices to become a more flexible and rhetorically capable writer-unlike Helen, who claimed to leave her "English" writing behind.

Harper believed learning to write was a "lifelong" endeavor, one that was still in process. Already comfortable in "English" writing from her high school experiences, she saw her new life writing in geology as the latest necessary step in her personal development. "I think [my writing experiences] build on each other. And it's important for scientist to have some background in English classes and looking at literature and that kind of stuff." She recognized change in her approaches to writing and more flexibility in her approach as a result of her science writing knowledge: "It's not like I have just one style of writing, which I think it different from high school me or even freshman-year me." Geology has expanded her ideas about what writing can look like and how to do it. Whereas Helen claimed to leave behind her high school writing style, Harper believes she built upon it to become more rhetorically flexible writing, an outcome that Poe et al. (2010) found most productive in their participants who were learning science communication. They note, "What emerges as perhaps most important is for students to develop flexible rhetorical repertoires and be able to apply elements of pervious communication experiences to new ones" (p. 186). Harper's comment reflects similar values.

Like Helen, Harper wouldn't jump to define herself as primarily a writer, but she embraces writer as a legitimate title for her ways of being and doing in geology:

It's not something I would introduce myself as, "Hi, I'm Harper, I'm a writer." I wouldn't do that but, yeah, I would consider myself a writer. I don't think that writer and a scientist are mutually exclusive things.

Her view against mutual exclusivity mirrors the progressive view she maintained about learning to write. She was putting these pieces together, building with them rather than replacing or exchanging one for the other. Harper's negotiations assembled a writing practice from her whole history of learning to write and one that recognized that writing complements scientific activity and mediates its successes.

Harper felt that writing so much in the geology major had prepared her for the writing life she would encounter in her future professional activity. She stated,

Any scientist that you talk to, who's in academia, basically tells you it's a writing career, it's not just doing science experiments. You write all the time: you write for proposal defenses, for conference speeches, and presentations, and manuscripts, obviously, and that takes a lot of time. And I've learned that by doing research [in classes] more than anything. It's just like the amount of time that goes into writing and researching past work and being able to write about [that work]. I have no doubt that writing will be a huge part of my career. 
Harper felt the writing intensified as she progressed through the scaffold stages of the curriculum, which to her indicated that she was stepping ever closer toward a fully realized professional identity. "You're getting closer to going out and being a scientist yourself, and being a scientist means you have to be able to write." For Harper, writing was essential for successful outcomes of scientific activity; to be a successful scientist and to pursue that work successful necessitated writing.

Harper believed that she developed this view-integrating writing deeply into her scientist identity-because of her engagement in the professional community. She explained:

It's not something that geologists really reflect on that much, I don't think. At least not in the classroom. I think you reflect on it more when you get involved with research outside of the classroom, and when you do things like attend conferences and talk to others and actually engage in the community.

In addition to the connections her classroom learning makes to professional activity, Harper also directly engaged with her professional community through the activity she names. That is, she has seen how the work she performs in the classroom overlaps with the authentic activity of professional geologists when she was among them. These experiences confirmed and refined her understanding of writing's function for geology through this direct engagement as she sees the authenticity and value of the work she has done in class. However, she did not separate this development from her previous experiences prior to geology. Rather, she integrated her frameworks productively to create a flexible set of practices that allow her to respond to different contexts. She drew upon her whole history of learning to write to explain her writing practice and ability from her childhood until now. She productively saw writing as an interdisciplinary act that benefits from integration of different disciplinary lens and approaches. She added her "English" experience to her scientific writing experience by emphasizing analytical skill and critical thinking. As she developed these skills and is faced with more writing tasks, she saw herself getting closer to the scientist identity she was working toward.

Students like Harper and Helen in the geology program have developed generative conceptions of writing because they have engaged writing within the context of their disciplinary activity. These two students are more reflective about, motivated toward, and engaged in their learning to write. Both recognize that writing is a life-long endeavor that differs according to context. Both understand that writing mediates the activity of their discipline. And both understand that writing is necessary for their successful integration into and participation within professional communities of geology. As Harper's last comment suggests, it was her engagement with this community-in the peripheral ways her geology program sponsors - that that best represented writing's function and value for geological activity. And that is perhaps the greatest strength of the geology program's curriculum and writing instruction: it engages students in learning and enables their professional identity development through legitimate peripheral participation in geological communities of practice.

\section{Changing Conceptions through Legitimate Peripheral Participation}

I invoke Lave and Wenger's (1991) legitimate peripheral participation to make two claims as to why geology majors are changing their conceptions around writing. First, the geology program has developed a curriculum and culture within its program that closely resembles professional geological communities of practice through legitimate, authentic activity of geology in and out of classrooms. Second, because geology students' activity is legitimate, authentic geological activity, they have already begun to enter into their professional communities in various peripheral ways and accordingly articulate their learning (to write) in terms of their community participation, engagement, and identity negotiation. They describe, imagine, or orient their sense of selves as 
(future) geology professionals and find all their learning-including learning to write-to be valuable because it enables them to be professionals who can participate meaningfully and seriously in these communities. In other words, students' experiences in geology not only prepare them to enter into these communities in the future but also already encourage and enable their engagement with these communities. In doing so, students change their conceptions about how work is done in geology (through its professional, mediational tools like writing, experimentation, and research) and how these practices mediate their professional identities.

Although Wenger (1999) developed his community of practice theory specifically for professional and organizational communities, the geology program (although an educational setting) has developed its own learning community that approximates the professional communities of practice that geology student may one day join. Wenger identifies three criteria that identify a community of practice: a joint enterprise or common interest that motivates the group and its practice, mutual engagement that creates and sustains member relationships, and a repertoire of practices that members all use to engage their common interest and mediate their activities. While I did not explicitly ask students about the "community of practice" of their major, their comments suggest the geology program meets the criteria in the following ways:

- Joint enterprise: the department's majors organize their activities as geological professionalism: developing student professionalization and generating new knowledge around geology through research and study.

- Mutual engagement: The department explores its enterprise not only through coursework but also through extracurricular research and seminars. While they primarily encounter one another in the classroom, students and instructors interact regularly outside of class as well through the Friday seminars with special speakers and discussions, collaborations on experiments and research, time spent together in the labs working collaboratively and independently, and trips to geological research sites and conferences. The members of this community encounter each other regularly in pursuit of their enterprise and not just in classroom settings.

- Shared repertoire: It is difficult to represent the entirety of a community's repertoire and equally difficult to capture it in only the 8 hours of interview data I collected, which was focused more on writing than the community itself. Still, examining students' comments however suggests a rich common repertoire. Students consistently cited methods of data analysis, the emphatic need to write to public audiences, many genres of writing, beliefs about effective writing (concise, factual, etc.), visualizations of data, data collection methods, geological concepts, experimentation and research, career trajectories, and professional standards. In other words, these students had a catalogue of shared resources they used to speak with one another, understand the activity of others, and evaluate that activity as it related to their community's enterprise.

As members of the geology department, students and instructors together pursue geological knowledge and promote dissemination and application of that knowledge through the tools of their shared repertoire as they work together in these many common activity sites. They form a learning community of practice, where "learning [is] not only a matter of course in the history of its practice, but also at the very core of its enterprise" (Wenger, 1999, p. 215).

Learning communities are especially powerful because of the ways they support identity negotiations and learning. Wenger (1999) argues that all learning is "not just the acquisition of memories, habits, and skills but the formation of an identity" (p. 96). His argument acknowledges and builds upon much education and psychology research that argues that learning shares a dialogic 
relationship with identity formation and negotiation, such as that of psychologist Ligorio (2009) who argues that, as students encounter new knowledge, they "are unavoidably compelled to think of themselves in new contexts...This implies not only a focus on what they do with knowledge but also on who they will be" (p. 37). Meyer and Land (2006), too, recognize that moving through threshold concepts to engage deeper learning and change conceptions "lead[s] not only to transfigured thought but a transfiguration of identity" (21). Davies (2006), in his chapter in Overcoming Barriers to Student Learning, articulates how this transformation in self is always situated within communities:

\section{[L]earning is an entrance into a community. The act of learning is an act of identity formation. In coming to see the world in a particular way, learners associate themselves with a community of people who share that way of thinking and practising (sic) and through this they position themselves in relation to others inside and outside of that community. (p. 71)}

New learning, in other words, presents each person the opportunity to develop new ways of being because of that knowledge. How people respond to and integrate new knowledge into their identities is to negotiate new identities for participation within these communities. Learning communities, like the geology program, especially sponsor the relationship between learning and identity because they "offer a place where new ways of knowing can be realized in the form of such an identity," an identity of participation (Wenger, 1999, p. 215).

As Harper and Helen demonstrated, geology majors have invested in their geological and writing education to prepare themselves for their future participation as geology professionals. Throughout our conversations, these students time and again stated that to participate as professionals in this field they would need writing. Harper, for example, said, "Being a scientist means being able to write." Edith too stated, "If you want to be a professional in geology, it's an expectation that you'll be able to effectively communicate your research or whatever it is you're doing in writing." These and other students told me clearly: they need to write effectively to become the scientists they want to be and to participate in their future communities of practice. These statements relate to students' developing professional identities-who they want to become-as scientists and professional geologists. They see writing as a tool for that identity and integrate writing willingly into their practice to become successful in those roles. They negotiate their new knowledge, changing conceptions, and desired identities through their experiences in the geology curriculum which sponsors this learning by engaging students in legitimate activity of their future communities. In this way, students learn about professional identities as geologists and devise a trajectory for their own development through their legitimate peripheral participation.

In Situated Learning: Legitimate Peripheral Participation, Lave and Wenger (1991) suggest legitimate peripheral participation as a way to describe how professionals best learn how to operate in their new communities. Drawing examples from apprenticeships, Lave and Wenger (1991) argue that newcomers in a professional community learn the community practice (including the enterprise, ways of engagement, and repertoire) through participation that is both legitimate and peripheral. Legitimate participation includes activity and work that is necessary to the success of the community's enterprise. That participation is peripheral, however, meaning that the activity is not central or paramount to that success. One such example comes from Vai tailors in West Africa. New tailors begin their apprenticeships by sewing on buttons and cuffs: work that is necessary to finishing a shirt, but is the least complicated and the easiest to fix if done incorrectly. The new tailors eventually move from buttons to the more complex work of sewing a shirt together, before doing the most critical work of cutting out the fabrics that comprise the shirt (p. 69-71). Importantly, all this activity serves a purpose beyond the learning of the new tailors. These newcomers move from work of minimal impact to the most impactful task, but all this work must happen to complete the 
community's practice of shirt-making. In this way, the tailors move slowly from their legitimate, peripheral work toward central participation as experienced members of the community.

Geology majors, too, learn to become members of their community through legitimate peripheral participation in geology communities. While many classroom activities are instances of what Freedman and Adam (1996) call "facilitated performance" (p.402)-activity for the sake of student learning - there are many examples of how students' work in and out of the classroom is legitimate and peripheral to the enterprise of professional geological communities. Students, like Helen and Harper, perform research experiments and prepare write-ups in class that they develop for publications. They also apply for scholarships and grants, like Harper's astronaut scholarship. They collaborate with faculty members on research projects that become conferences presentations and publications. Tyler, Helen, and Edith had just returned from one such conference. They participate in summer field research projects that inform their own learning and research and contribute to faculty projects. All this activity is work that would happen anyway. Faculty would perform their research, and publications and conferences would move forward whether students were there to learn or not. And their participation does not determine the success of the enterprise but does contribute meaningfully to it, often through discursive genres (publications, presentations, reports, etc.). This activity is legitimate, peripheral, and participatory within the community of practice they hope to join, the professional geological community. Through this participation they see their classroom learning have active, authentic application in the community, particularly the use of writing. As Ambrose et al. (2010) acknowledge in How Learning Works, without a clear understanding why new knowledge is relevant to their lives, students "may see little value in mastering it and may fail to engage in behaviors required for deep learning" (p. 69). Through their legitimate peripheral participation, however, students see for themselves the value of learning to write in geology for their present and future participation as professional geologists.

Geology students' participation occurs not only in these forms of direct engagement but also through imagination. In Communities of Practice, Wenger (1999) describes ways that people participate in communities of practice, including engagement and imagination. Engagement includes direct participation with the community: negotiating the practices, goals, and meanings of the community; building relationships with members; and moving into, within, and through the community (p. 174); the kinds of activities described above. Imagination, on the other hand, does not necessarily involve direct interaction with the community. Instead, at the name suggests, imagination is often removed from local workings of the community. Wenger describes imagination as "a process of expanding our self by transcending time and space and creating new images of the world and ourselves” (p. 176). Rather than being limited by our physical and temporal access to communities, people participate in communities by orienting their sense of self towards those communities in imagination.

Wenger (1999) emphasizes that imagination is not about "personal fantasies, withdrawals from reality, or mistaken...conclusions" (p. 177). Rather, the learner engages and sees possibilities, connections, futures that reach beyond the present and local to new "images...that become constitutive of the self" (p. 177). Imagination helps us to envision our relationship to others-past, present and future; local and distant-and make sense of our place among them, apart from them, and within them. It allows us to expand our sense of self into other communities and possibilities for being and belonging. The Michigan sports fan displaced in Ohio, the American proud of her Polish immigrant ancestry, the student practicing lab experiments-these all use imagination to describe, justify, and situate their activities and belonging through and apart from time and space. Wenger offers an instructive example of imagination:

This brings to mind a story about the two stonecutters who are asked what they are doing. One responds: "I am cutting this stone in a perfectly square shape." The other 
responds: "I am building a cathedral." Both answers are correct and meaningful, but they reflect different relations to the world. [...] Their experiences of what they are doing and their sense of self in doing it are rather different. This difference is a function of imagination. As a result, they may be learning very different things from the same activity. (p.176)

While the first stonecutter focuses on the explicit action he performs, the second sees his activity in relations to his purpose and goals. His activity extends to relations, communities, and networks beyond his immediate circumstance.

Geology participants' own articulation of their writing reflects the same sort of imagination of the second stonecutter. Because they have developed identities that situate writing as a practice for participation in geological communities, they do not necessarily see "writing" as separate from the activity of their community. They do not respond as the first stonecutter did: "I am just writing." Instead, they understand writing much as the second stonecutter understood his chiseling: as a process of performing research and contributing new knowledge to the community. They can imagine how this writing functions to the production of meaning in the community.

Other research too affirms how the deployment of situated learning and imagination succeeds in encouraging student learning in the geology program. In How Learning Works, the strategies that Ambrose et al. (2010) suggest for motivating students to engage in learning rely heavily on imagination. These strategies include:

- Connect the material to student interests

- Provide authentic, real-world tasks

- Show relevance to students' current academic lives

- Demonstrate the relevance of higher-level skills to students' future professional lives. (p. 83-84).

As the geology program has done, these strategies suggest creating classroom activities and experiences that connect beyond the immediate class to other communities, to "allow students to vividly and concretely see the relevance and value" of new knowledge and to recognize its validity and use outside of the classroom (p. 83). Poe, Lerner, and Craig's Learning to Communicate in Science and Engineering (2010) likewise saw their participants learning about writing as they imagined its function for their future professional identities. Their participants negotiated writing tasks in a biology lab, performing "authentic" research tasks that correspond directly to or closely mirror the work of biologists. The authors argued, "For our three participants, the authenticity of the tasks fed tangibly into the identities they currently held and imagined they would hold" (p. 79, emphasis added). Like Poe, Lerner, and Craig's (2010) participants, my geology participants found that engaging writing through geological research activity enabled them to see the future possibilities of writing. All 22 of my geology participants describe writing's future application as a necessary tool for their participation as a professional geologist. By making connections between academic learning and future professional lives obvious, the geology program enables students to imagine how class content will allow them to succeed in their target communities. In the case of this study, students invest in learning to write when they can imagine how writing functions as a participatory practice for professional geological communities.

Through legitimate peripheral participation and imagination, the geology program enables students to see how writing allows participation in professional communities for geology. Students seeking to be scientists or other geological professionals recognize writing as an essential tool in geology's 
shared repertoire. To become professionals capable of meaningful participation, geology students take learning to write seriously, and change their conceptions as a result.

\section{Conclusion}

The conceptions students hold about writing will impact their engagement in learning about writing and their future deployment of that learning. My geology student participants have developed conceptions of writing that are specific to their discipline and promote positive relationships with writing. Students in this program understand that writing mediates their disciplinary activity and is required for serious participation as future geology professionals. As a result, some geology majors, like Harper and Helen, have passed or are working through threshold concepts of writing, such as that learning to write is a continual process; writing requires a thoughtful process that includes practice, feedback, and revision; and writing is a contextual practice that differs according to the situation and audience. They have also developed a deeper understanding of how, where, and why writing occurs, describing writing as part of the process of research and experimentation that drives geological knowledge.

These changing conceptions result from writing instruction that is situated within the legitimate practices of geological activity systems. Students learn to work in ways authentic to geology professionals, deploying similar tools with a similar motive and object in mind: discovery, promotion, and application of geological knowledge. Writing in this curriculum is not a separate object intersecting with geological activity but rather an operationalized tool in services of the community's motives. As students perform their curricular and extra-curricular research, reading, and engagement in their major and other geological communities, they learn about and use writing to contribute to each community and prepare for their future professional work. Through these activities, the geology program emphasizes that to participate seriously in professional geological communities requires members to take up a standard set of practices and that writing is among them. To become a geologist requires the ability to write according to the community's norms, standards, and expectations. Students engage in learning to write deeply, then, in order to become that geologist, in order to develop their identities for participation.

To achieve similar outcomes, writing instruction in other majors and programs too should seek to create experiences that are legitimate and authentic to the communities that students want to join. Students should see writing's function contextualized within specific communities and activities that pursue motives similar to their own majors, disciplines, and imagined professions. Attentive writing instruction must supplement those connections, so that students explore the motives and content of their disciplines while also learning about community expectations for writing, receiving feedback on their drafts, and exploring the rhetorical tools of disciplinary genres. Most importantly, students should learn how writing moves, circulates, and mediates the motives and outcomes of these communities, which they might learn through experiences of direct engagement in professional and disciplinary communities like conferences, internships, collaborations with faculty, and service learning.

\section{References}

Adler-Kassner, Linda, \& Wardle, Elizabeth (2015). Naming what we know: Threshold concepts of writing studies. University Press of Colorado.

Ambrose, Susan A., Bridges, Michael W., DiPietro, Michele, Lovett, Marsha C., \& Norman, Marie K. (2010). How learning works: Seven research-based principles for smart teaching. Jossey-Bass.

Anson, Chris M., \& Moore, Jessie L. (2017). Critical transitions: Writing and the question of transfer. The WAC Clearinghouse. 
Ball, Cheryl E., \& Loewe, Drew M. (Eds.). (2017). Bad ideas about writing. Digital Publishing Institute; West Virginia University Libraries.

Baird, Neil, \& Dilger, Brad. (2017). How students perceive transitions: Dispositions and transfer in internships. College Composition and Communication, 68(4), 684.

Bazerman, Charles. (1997). Discursively structured activities. Mind, Culture, and Activity, 4(4), 296-308.

Bazerman, Charles. (2015). Writing speaks to situations through recognizable forms. In Linda Adler-Kassner, \& Elizabeth Wardle (eds.). Naming what we know: Threshold concepts of writing studies (pp. 35-37). University Press of Colorado.

Bazerman, Charles, \& Russell, David R. (2003). Writing selves, writing societies: Research from activity perspectives. WAC Clearinghouse. https://wac.colostate.edu/books/perspectives/selves-societies/

Beaufort, Anne. (1999). Writing in the real world: Making the transition from school to work. Teachers College Press.

Bizzell, Patricia. (1982). Cognition, convention, and certainty: What we need to know about writing. PRE/TEXT, 3(3), 213-43.

Carroll, Lee A. (2002). Rehearsing new roles: How college students develop as writers. Southern Illinois University Press. https://wac.colostate.edu/books/ncte/carroll/

Carter, Michael. (2007). Ways of knowing, doing, and writing in the disciplines. College Composition and Communication, 58(3), 385-418.

Davies, Peter. (2006). Threshold concepts: How can we recognise them? In Ray Land, \& Jan Meyer (Eds). Overcoming barriers to student learning: Threshold concepts and troublesome knowledge (pp. 70-84). Routledge.

Dias, Patrick, Freedman, Aviva, Medway, Peter, \& Par, Anthony. (2013). Worlds apart: Acting and writing in academic and workplace contexts. Taylor and Francis.

Downs, Douglas, \& Wardle, Elizabeth. (2007). Teaching about writing, righting misconceptions: (Re)envisioning "first-year composition" as "introduction to writing studies". College Composition and Communication, 552-584.

Duit, Reinders, \& Treagust, David F. (2003). Conceptual change: A powerful framework for improving science teaching and learning. International journal of science education, 25(6), 671-688.

Engeström, Yrjö. (1987). Learning by expanding: An activity-theoretical approach to developmental research. Orienta-Konsultit.

Entwistle, Noel. (2008). Threshold concepts and transformative ways of thinking within research into higher education. In Ray Land, Jan Meyer, \& Jan Smith (Eds.). Threshold concepts within the disciplines (pp. 2136). Sense Publishers.

Estrem, Heidi. (2015). Disciplinary and professional identities are constructed through writing. In Linda Adler-Kassner, \& Elizabeth A. Wardle (Eds.). Naming what we know: Threshold concepts of writing studies (pp. 55-56). Utah State University Press.

Freedman, Aviva, \& Adam, Christine. (1996). Learning to write professionally: "Situated learning" and the transition from university to professional discourse. Journal of Business and Technical Communication, $10(4), 395-427$.

Gee, James P. (2000). Identity as an analytic lens for research in education. Review of Research in Education, 25, 99-125.

Goldschmidt, Mary. (2014). Teaching writing in the disciplines: Student perspectives on learning genre. Teaching \& Learning Inquiry, 2(2), 25-40.

Gooding, Julia, \& Metz, Bill. (2011). From misconceptions to conceptual change. Science Teacher, 78(4), 34-37.

Ivanič, Roz. (1998). Writing and identity: The discoursal construction of identity in academic writing. John Benjamins Publishing Company.

Land, Ray, \& Meyer, Jan H.F. (Eds.). (2006). Overcoming barriers to student learning: Threshold concepts and troublesome knowledge. Routledge.

Land, Ray, Meyer, Jan H.F., \& Smith, Janice. (2008). Threshold concepts within the disciplines. Sense Publishers. 
Lave, Jean, \& Wenger, Etienne. (1991). Situated learning. Legitimate peripheral participation. Cambridge University Press.

Leonard, Mary J., Kalinowski, Steven T., \& Andrews, Tessa C. (2014). Misconceptions yesterday, today, and tomorrow. CBE-Life Sciences Education, 13(2), 179-186.

Leont'ev, Aleksei N. (1978). Activity, consciousness, and personality. Prentice-Hall.

Lerner, Neal. (2015). Writing is a way of enacting disciplinarity. In Linda Adler-Kassner, \& Elizabeth Wardle (Eds.). Naming what we know: Threshold concepts of writing studies (pp. 40-41). University Press of Colorado.

Leydens, Jon A., \& Santi, Paul. (2006). Optimizing faculty use of writing as a learning tool in geoscience education. Journal of Geoscience Education, 54(4), 491-502.

Ligorio, M. Beatrice. (2009). Identity as a product of knowledge building: The role of mediated dialogue. Qwerty: Rivista interdisciplinare di tecnologia, cultura, e formazione, 4(1), 33-46.

Lucariello, Joan, \& Naff, David. (2010). How do I get my students over their alternative conceptions (misconceptions) for learning?: Removing barriers to aid in the development of the student. American Psychological Association. https://www.apa.org/education/k12/misconceptions

Meyer, Jan H.F., \& Land, Ray. (2005). Threshold concepts and troublesome knowledge (2): Epistemological considerations and a conceptual framework for teaching and learning. Higher Education, 49(3), 373388.

Meyer, Jan H. F., \& Land, Ray (Eds.). (2006a). Threshold concepts and troublesome knowledge: an introduction. In. Ray Land \& Jan H.F. Meyer (Eds). Overcoming barriers to student understanding: Threshold concepts and troublesome knowledge (pp. 3-18).

Meyer Jan H. F., \& Land, Ray (Eds.). (2006b). Threshold concepts and troublesome knowledge: Issues of liminality. In Ray Land, \& Jan Meyer (Eds). Overcoming barriers to student understanding: Threshold concepts and troublesome knowledge (pp. 19-32). Routledge.

Miami University. (n.d.) B.S. Geology. Department of Geology and Environmental Earth Science, Miami University. https://www.miamioh.edu/cas/academics/departments/geology/academics/majors/bsgeology/index.html

National Research Council. (1997). Science teaching reconsidered: A handbook. The National Academies Press.

Odell, Lee, Goswami, Dixie, \& Herrington, Anne. (1983). The discourse-based interview: A procedure for exploring the tacit knowledge of writers in nonacademic settings. In Mosenthal, Peter, Tamor, Lynne, \& Walmsley, Sean A. (Eds). Research on writing: Principles and methods (pp. 220-236). Addison-Wesley Longman Ltd.

Paré, Anthony, \& Dias, Patrick (Eds.). (2000). Transitions: Writing in academic and workplace settings. Hampton Press.

Perkins, David. (2008). Beyond understanding. In Ray Land, Jan H.F. Meyer, \& Jan Smith (Eds.). Threshold concepts within the disciplines (pp. 3-20). Sense Publishers.

Petraglia, Joseph. (1995). Spinning like a kite: A closer look at the pseudotransactional function of writing. JAC, 15(1), 19-33.

Poe, Mya, Lerner, Neal, \& Craig, Jennifer. (2010). Learning to communicate in science and engineering: Case studies from MIT. Massachusetts Institute of Technology Press.

Roozen, Kevin. (2015). Writing is a social and rhetorical activity. In Linda Adler-Kassner, \& Elizabeth A. Wardle (Eds.). Naming what we know: Threshold concepts of writing studies (pp. 17-19). Utah State University Press.

Rose, Shirley. (2015). All writers have more to learn. In Linda Adler-Kassner, \& Elizabeth A. Wardle (Eds.). Naming what we know: Threshold concepts of writing studies (pp. 59-60). Utah State University Press.

Roth, Wolff-Michael, \& Lee, Yew-Jin. (2007). "Vygotsky's neglected legacy": Cultural-historical activity theory. Review of Educational Research, 77(2), 186-232.

Russell, David R. (1995). Activity theory and its implications for writing instruction. In Joseph Petraglia (Ed). Reconceiving writing, rethinking writing instruction (pp. 51-77). Routledge. 
Russell, David R. (2015). Writing mediates activity. In Linda Adler-Kassner, \& Elizabeth A. Wardle (Eds.). Naming what we know: Threshold concepts of writing studies (pp. 26-27). University Press of Colorado.

Stets, Jan, \& Burke, Peter J. (2000). Identity theory and social identity theory. Social Psychology Quarterly, 63(3), 224-237.

Spinuzzi, Clay. (1996). Pseudotransactionality, activity theory, and professional writing instruction. Technical Communication Quarterly, 5(3), 295-308.

Thaiss, Chris, \& \& Zawacki, Terry. (2006). Engaged writers, dynamic disciplines: Research on the academic writing life. Boynton/Cook Heinemann.

Wardle, Elizabeth. (2004). Identity, Authority, and Learning to Write in New Workplaces. Enculturation, 5(2).

Wenger, Etienne. (1999). Communities of practice: Learning, meaning, and identity. Cambridge University Press.

Wilcox, Miranda. (2017). Closing the loop: Strengthening disciplinary writing in an English BA program. Composition Forum, 35. https://compositionforum.com/issue/35/byu.php

Yancey, Kathleen B. (2015). Learning to write effectively requires different kinds of practice, time, and effort. In Linda Adler-Kassner, \& Elizabeth A. Wardle (Eds.). Naming what we know: Threshold concepts of writing studies (pp. 64-65). Utah State University Press.

\section{Notes}

${ }^{1}$ While I did not collect specific data on instructor beliefs or behaviors regarding teaching writing, anecdotally, the instructors I did interact with were all excited for this project and to talk about the writing their students were doing. In casual conversations had while visiting geology classrooms to recruit participants, instructors reported the learning they saw taking place through these kinds of assignments and particularly noted the relationship these projects had to the profession. They told me that these writing tasks illustrated and offered practice in the typical work of geological professionals and that the students were learning what they would need to know as future geologists. Consciously or not, these instructors emphasized to me the necessity of writing as a mediational tool for their discipline.

\section{Contact Information}

Enrique Paz

Position Assistant Professor of English

Institution Southern Illinois University Carbondale

Email: enrique.paz@siu.edu

\section{Complete APA Citation}

Paz, Enrique. (2022, February 18). Changing conceptions of writing through situated activity in a geology major. Across the Disciplines, 18(3/4), 320-346. https://doi.org/10.37514/ATD-J.2022.18.3$\underline{4.07}$ 